The methodological principles of the research are based on the principles of historicism, scientificity and dialectical approach to historical phenomena, while the scientific novelty lies in a comprehensive approach to the process of forming a small cooperative loan in the Ukrainian lands of the Russian Empire. Based on the analysis of the abovementioned sources, little-known aspects of small credit cooperation and its impact on the economy of Russian Ukraine in the early XX century were discovered. The conclusions indicate the relevance of cooperative issues in modern Ukrainian realities, especially after the Verkhovna Rada adopted a law on land market.

Keywords: Russian Empire, Ukraine, credit, savings and loan societies, credit societies.

DOI: $10.33766 / 2524-0323.90 .69-76$

УДК 340.115: 615.1

О. С. Ховпун,

кандидат юридичних наук, доцент, завідувач кафедри кримінального права, процесу та криміналістики

Академії праці, соціальних відносин і туризму

(м. Київ, Україна)

e-mail: khovpun3322@gmail.com

iDhttps://orcid.org/0000-0002-5753-966X

\title{
ЗНАЧЕННЯ ГЕРМЕНЕВТИЧНОГО МЕТОДУ АДМІНІСТРАТИВНО-ПРАВОВОГО ЗАБЕЗПЕЧЕННЯ ФАРМАЦІЇ
}

Стаття присвячена з'ясуванню значення герменевтичного методу адміністративно-правого забезпечення фармації. Доведено, що застосування герменевтичного методу сприяє отриманню повноти тлумачення норм закону на рівні ідеї, тексту, промови. Встановлено, що герменевтичний методпізнання дозволяє проводити інтерпретацію текстів нормативних актів, інших правових джерел з урахуванням історичних, ідеологічних, економічних, психологічних, соціологічних обставин прийняття та застосування закону. Обгрунтовано, що розуміння, тлумачення й застосування фармацевтичного законодавства повинні бути обмежені абсолютною цінністю - життям люДини та їі здоров' ям.

Ключові слова: фармація, методи, герменевтика, герменевтичний метод, наукове дослідження.

Постановка проблеми. Отримання повноти результатів наукового дослідження можливе лише при одночасному застосуванні загальнонаукових та спеціальних методів наукового пізнання. Залежно від предмета правого дослідження, його змістового навантаження, значення для розвитку прав людини, держави обираються відповідні методи. Серед них виокремлюються найбілыш значущі, які можуть розкрити сутність конкретно визначеного предмета дослідження. Останнім часом найбільш часто застосовують герменевтичний метод, який дозволяє з' ясувати смисл юридичного тексту закону та окремих правових джерел. Притім слід констатувати наявність прогалин щодо методологічного забезпечення дослідження адміністративно-правового забезпечення фармації. Унаслідок цього виникає потреба у виявленні значення методології

(C) Ховпун О. С., 2020 
наукового пізнання адміністративно-правового забезпечення фармації, зокрема герменевтичного методу.

Аналіз останніх досліджень і публікащій. До проблематики юридичної герменевтики, герменевтичного підходу, герменевтичного методу зверталися дослідники з різних галузей знань. Незважаючи на різну галузеву спрямованість, їхні роботи визначили базовий підхід до таких правових явищ. Зокрема стаття О. П. Дзьобаня і В. Л. Яроцького «Герменевтичний метод у сучасних цивілістичних дослідженнях: до питання про доцільність застосування» (2017 р.) [1] присвячена засновуванню цього методу в цивільному праві. Загальний опис подібного методу надається в роботі I. П. Косцової «Герменевтичний метод тлумачення норм права: історична та юридична дивергенщія» (2015 р.) [2]. До пояснення цього методу звертається і С. I. Кожушко «Герменевтичний метод як процес еволющії предмета» (2015р.) [3]. Попри розроблені засади, застосування такого методу щодо дослідження правових категорій, окремого обгрунтування його використання для пізнання адміністративно-правових понять практично не здійснювалося, тому питання визначення значення герменевтичного методу адміністративно-правого забезпечення фармації $є$ нагальною потребою.

Формулювання цілей. Метою статті є визначення значення герменевтичного методу адміністративно-правого забезпечення фармації. Досягнення цієї мети можливе при розкритті таких завдань, як: виявлення характерних ознак герменевтичного методу в юридичних дослідженнях, з'ясування поняття герменевтичного методу в дослідженнях адміністративно-правого забезпечення фармації, обгрунтування доцільності його застосування.

Виклад основного матеріалу. У юридичній літературі справедливо визначено, що правова герменевтика - метод наукового дослідження, призначений для виявлення смислу юридичного тексту, виходячи з його об'єктивних (значення слів та їх історично обумовлені варіації) і суб'єктивних (наміри автора) підстав, інтерпретаціїта роз'яснення змісту юридичного тексту, зафіксованого в документі [1, с. 8]. Причому для характеристики такого правового феномену дослідники застосовують такі терміни, як: «метод», «підхід», оскільки методологічний підхід - це комплекс основних вихідних установок, включаючи певне початкове уявлення про досліджуваний об'єкт, а також обумовлені цими уявленнями стратегія, тактика й методи дослідження [4, с. 295]. Можливість застосування в методології не лише феномену методу, а й інших понять обумовлена тим, що методологія - явище інтегральне, яке охоплює систему компонентів: світогляд і фундаментальні загальнотеоретичні конщепщії, загальні філософські закони й категорії, загальні та окремі методи пізнання [5, с. 93]. Отже, термін «підхід» у методологіїдослідженні $\epsilon$ широким поняттям, що охоплює і стратегію, і методи пізнання.

Метод герменевтики своїми витоками пов' язаний із теологією [3, с. 117]. Дійсно, первинно тлумачення тексту застосовувалося виключно до розуміння символу релігійного тексту. Згодом цей метод стали досліджувати й у філософії. Його сутність та завдання істотно переосмислив Ф. Д. С. Шлейермахер, який у своїй конщепщії на перше місце поставив феномен розуміння, вважаючи його якимось універсальним процесом. Крім того, дослідник сформулював один із основоположних принщипів герменевтики: принщип «герменевтического кола». Суть його в тому, що ціле розуміється на основі розуміння частини, а частина - виходячи з цілого [6, с. 60]. Згодом виокремлюються засади юридичної герменевтики, на підгрунті того, що «між народом 
і державою, ... науковим життям і університетом існує відношення, згідно з яким, загальний дух, єдина форма життя знаходяться в структурному взаємозв'язку, у якій вони виражаються», адже «існує відношення частин до цілого, у якому окремі частини отримують своє значення від цілого, а ціле - свій сенс» [7, с. 316]. Поступово дослідники виокремлюють для юридичної герменевтики стан існування напруги між відомостями тексту (закону), з одного боку, і тим текстом, який є результатом його застосування в конкретній ситуації тлумачення (судовий вирок) - $з$ іншого [8, с. 190]. Отже, розуміння будь-якого явища обумовлено загальними ідеями, що закладаються в нього як у цілісний феномен, тобто не може тлумачитися окрема частина без цілісного. Таке розуміння є найбілыш повним для тлумачення символів, а тому герменевтика стає окремим науковим напрямком і методом наукового пізнання.

Зауважимо, що герменевтичний підхід віднесено до некласичних (сучасних) методологічних методів, який орієнтований на розуміння сущого й належного, на з'ясування перетинів тексту й інтерпретатора [4, с. 304]. Розуміючи доктринальній підхід до герменевтичного підходу, при дослідженні адміністративно-правого забезпечення фармації буде застосовано термін «герменевтичний метод», який є білыш вузьким, ніж «герменевтичний підхід», що, зі свого боку, дасть можливість розглянути саме застосування методу до відповідного предмета дослідження.

Застосування герменевтичного методу сприяє отриманню повноти тлумачення норм закону на рівні ідеї, тексту, промови. Відбувається розуміння тексту закону, тому що правова ідея, реалізована в процесі правотворчості у формі того чи іншого закону, фіксується за допомогою тексту, у вигляді тексту закону доводиться до застосовувача права, який повинен дешифрувати знаковий ряд (текст) [2, с. 155]. Причому за допомогою цього методу процедура тлумачення закону охоплює такі стадії, як розуміння закону (з точки зору символів тексту, тобто без суб'єктивного аналізу), його тлумачення та застосування. Основною засадою розуміння, тлумачення та застосування закону в аспекті герменевтики є об'єктивізм, що передбачає безпосереднє, пряме застосування закону.

Розуміння закону через об' єктивізм його тлумачення обумовлено тим, що герменевтика завжди була теологічною; вона стала не лише мистецтвом тлумачення й роз'яснення, але й універсальним ключем до віднайдення істини, як крайня точка есенщіалістської парадигми мови. Причому суть герменевтики полягає в тому, що слід враховувати різні обставини створення тексту, зокрема історичні, ідеологічні, психологічні, сощіологічні тощо [9, с. 159-160]. Такий підхід надає можливість тлумачити будь-який закон у всій його повноті.

Повнота тлумачення закону, з точки зору герменевтичного методу, повинна враховувати обставини прийняття закону. Так дослідник може звертатися до пояснювальних записок прийняття закону, які чітко вказують мету, доцільість прийняття саме цього закону. Окремо необхідно звертатися й до статистичного методу, що дозволить виявити стан суспільних відносин за статистичними даними, які існували на момент його прийняття. Крім цього, додаткове застосування історичного методу дасть можливість виявити стан подій, що сприяли прийняттю закону. Також може враховуватися й психологічний стан автора закону, іноді доречно виявляти і 
його мотиви, дाя того щоб виокремити систему суб'єктивних та об'єктивних чинників при прийнятті закону. Отже, герменевтичний метод може використовуватися як самостійно, так і в комплексі з іншими методами наукового дослідження.

Самостійно герменевтичний метод тлумачення закону застосовується таким чином: за змістом мови (граматичне тлумачення), за сукупністю взаємозв' язків з іншими законами (систематичне), за історичною ситуацією (історичне тлумачення), за змістом та метою закону (телеологічне) [10, с. 21]. Наведене вказує на універсальність герменетивчного методу щодо тлумачення норм закону. Універсальність обумовлена тим, що символ є первинним та ідеальним, і це вказує на існування певного «духу» закону. Такий підхід дає можливість обійти штучне тлумачення закону, яке використовується для задоволення інтересу окремої людини або окремої групи суб'єктів. Через те бажано застосовувати герменевтичний метод, зокрема в роботі Великої Палати Верховного Суду України.

Окрім універсальності, істинності розуміння, тлумачення закону при застосування герменевтичного методу у юридичних джерелах виокремлюють і принцип достатності розуміння. Згідно з цим методом, правильне розуміння закону практично не можливе, а замість цього, вистачить лише рівня сприйняття й усвідомлення тексту закону, який є достатнім для вирішення конкретного спору або проблеми і який не є явно несправедливим [11, с. 161]. 3 таким підходом слід погодитися, оскільки під розумінням слід осмислювати мистецтво осягнення знаків, які передає свідомість однієї особи та сприймає інша через зовнішнє письмове вираження [2, с. 156] . Безумовно, розуміння закону буде обмежено знаннями, досвідом особи, яка здійснює пізнання та внутрішнє тлумачення закону. Тому при здійсненні пізнавальної діяльності тексту закону необхідне застосування максимальної об'єктивності особи, оскільки герменевтика базується на аналізі та роз' ясненні.

Узагальнюючи, зазначимо, що герменевтичний метод пізнання у юридичних дослідженнях має особливості, які обумовлені особливим предметом інтерпретаціï/розуміння тексту закону, інших правових джерел; зауважимо, що при його застосуванні повинні домінуватипринципи істинності, об' єктивізму, універсальності, а вторинним має виступає принцип достатності.

Використання герменевтичного методу адміністративно-правого забезпечення фармації сприяє тлумаченню тексту закону в аспекті фармацевтичної та юридичної наук. Розуміння закону з точки зору різних наукових підходів утворює повноту тлумачення закону. Причому саме в цій сфері повинні враховуватися обставини створення закону. Наприклад, прийняття змін до фармацевтичного законодавства може бути обумовлено боротьбою з COVID-19. Саме крізь призму намагання здійснення боротьби з цією хворобою повинно інтерпретуватися прийняте законодавство.

Крім того, на прийняття фармацевтичного законодавства безпосередньо впливає стан фармації як науково-господарської діяльності. Цей стан має постійну динаміку, обумовлену новими фармацевтичними інноваціями та розвитком фармацевтичного виробничого ланщюга. Притому первинність при прийнятті закону та його тлумаченні повинна надаватися не суб'єктам-виробникам ліків, а людині, яка потребує терапевтичного впливу ліків на здоров'я та взагалі на підтримку життя. Отже, з точки 
зору герменевтичного методу прийняття фармацевтичних законів повинно спрямовуватися на задоволення інтересів людини, а не господарюючих суб'єктів (підприємців) у цій сфері.

Завдяки застосуванню герменевтичного методу у сфері адміністративно-правого забезпечення фармації виникає можливість виокремити первинні та вторинні інтереси суб'єктів. Так при інтерпретації фармацевтичного законодавства на перше місце повинна ставитися людина, їі здоров'я, життя, тому дощільність прийняття й застосування відповідного нормативного акту слід розглядати з врахуванням саме цього аспекту. При виникненні подвійного тлумачення норм фармацевтичного закону доцільно надавати перевагу інтересам людини. Безумовно, необхідно встановлення балансу інтересів, що передбачає справедливу рівновагу. Однак повнота пропорційності може бути порушена при виникненні загрози життю людини. Тобто розуміння, тлумачення й застосування фармацевтичного законодавства повинні бути обмежені абсолютною цінністю - життям людини та її здоров' ям. Такий підхід потребує окремого осмислення у юридичних дослідженнях у сфері фармацевтичного законодавства, оскільки він має безпосередній вплив на прийняття закону та подалыше його тлумачення. Крім того, він повинен бути закріплений у засадах фармацевтичного законодавства як первинний принцип при реалізації фармацевтичних правовідносин.

Висновки. Проведене наукове дослідження дозволяє запропонувати такі міркування й висновки.

1. Герменевтичний метод пізнання дозволяє проводити інтерпретацію текстів нормативних актів, інших правових джерел з урахуванням історичних, ідеологічних, економічних, психологічних, соціологічних обставин прийняття та застосування закону.

2. Герменевтичний метод у юридичних науках має особливий предмет - текст закону, інших правових джерел. При його застосуванні повинні домінувати принципи істинності, об'єктивізму, універсальності; вторинним є принщип достатності.

3. Визначено, що використання герменевтичного методу в дослідженнях адміністративно-правого забезпечення фармації дозволяє тлумачити тексти законів в аспекті фармацевтичної і юридичної наук.

4. Обгрунтовано, що розуміння, тлумачення й застосування фармацевтичного законодавства повинні бути обмежені абсолютною цінністю - життям людини та іiі здоров' ям, тому значення герменевтичного методу адміністративно-правого забезпечення фармації полягає в тому, що він надає можливість виокремити універсальні інтереси суб'єктів. Застосування герменевтичного методу в юридичних дослідженнях супроводжується обов'язковим застосуванням інших методів пізнання, зокрема історичного, статистичного, системно-структурного, аксіологічного тощо.

Отже, проведене дослідження значення герменевтичного методу для адміністративно-правого забезпечення фармації $є$ актуальним та перспективним напрямом подалыших наукових розвідок.

\section{Використані джерела:}

1. Дзьобань О. П., Яроцький В. Л. Герменевтичний метод у сучасних цивілістичних дослідженнях: до питання про доцільність застосування. Інформація і право. 2017. № 2. С. 5-12. 
2. Косцова І. П. Герменевтичний метод тлумачення норм права: історична та юридична дивергенщія. Вісник Національного університету «Львівська політехніка». Юридичні науки. 2015. № 827. С. 153-158.

3. Кожушко С. І. Герменевтичний метод як процес еволюції предмета. Науковий Вісник Міжнародного гуманітарного університету. Серія: Юриспруденція. 2015. Вип. 14 (1). С. 116-119.

4. Данильян О. Г. Дзьобань О. П. Організація та методологія наукових досліджень: навч. посіб. Харків, 2017. 448 с.

5. Керимов Д. А. Методология права: предмет, функции, проблемы философии права. Москва: Изд-во СГУ, 2011. 521 с.

6. Шаев Ю. М. Фенеменология смысла в герменевтике: опыт семиотического анализа. Вестник Ставропольского государственного университета. 2009. № 61. С. 58-66.

7. Дильтей В. Собрание сочинений: В 6 т. Т. 3. Построение исторического мира в науках о духе. Москва: Три квадрата, 2004. 419 с.

8. Нетреб'як О. Сутність та значення правової герменевтики. Підириємництво, господарство і право. 2017. № 5. С. 189-192.

9. Чернобров А. А. Герменевтика: научный подход: эссенщиалистический анализ прагматики. Сибирский педагогический журнал. 2009. № 1. С. 158-166.

10. Герменевтика: история и современность. Москва: Мысль. 1986. 303 с.

11. Мережко А. А. Юридическая герменевтика и методология права. Проблеми фрiлосоdiï npaba. 2003. T. 1. C. 159-162.

\section{References:}

1. Dzoban, O. P., Yarotskyi, V. L. (2017) Hermenevtychnyi metod u suchasnykh tsyvilistychnykh doslidzhenniakh: do pytannia pro dotsilnist zastosuvannia Informatsiia i pravo - Information and law, 2, 5-12. [in Ukrainian].

2. Kostsova, I. P. (2015) Hermenevtychnyi metod tlumachennia norm prava: istorychna ta yurydychna dyverhentsiia. Visnyk Natsionalnoho universytetu «Lvivska politekhnika». Yurydychni nauky - Bulletin of the National University "Lviv Polytechnic". Legal sciences, 827, 153-158. [in Ukrainian].

3. Kozhushko, S. I. (2015) Hermenevtychnyi metod yak protses evoliutsii predmeta. Naukoryi visnyk Mizhnarodnoho humanitarnoho universytetu. Seriia: Yurysprudentsiia - Scientific Bulletin of the International Humanities University. Series: Jurisprudence, 14(1), 116-119. [in Ukrainian].

4. Danylian, O. H. Dzoban, O. P. (2017) Orhanizatsiia ta metodolohiia naukovykh doslidzhen: navch. posib. Kharkiv. [in Ukrainian].

5. Kerimov, D. A. (2017) Metodologiia prava: predmet, funktsii, problemy filosofii prava. Moskva: Izd-vo SGU. [in Russian].

6. Shaev, Iu. M. (2009) Fenemenologiia smysla v germenevtike: opyt semioticheskogo analiza. Vestnik Stavropolskogo gosudarstvennogo universiteta - Bulletin of Stavropol State University, 61, 58-66. [in Russian].

7. Diltei, V. (2004) Sobranie sochinenii: (Vol. 1-6); vol. 3. Postroenie istoricheskogo mira v naukakh o dukhe. Moskva: Tri kvadrata. [in Russian].

8. Netrebiak, O. (2017) Sutnist ta znachennia pravovoi hermenevtyky. Pidpryiemnytstoo, hospodarstvo i pravo - Entrepreneurship, economy and law, 5, 189-192. [in Ukrainian].

9. Chernobrov, A. A. (2009) Germenevtika: nauchnyi podkhod: essentsialisticheskii analiz pragmatiki. Sibirskii pedagogicheskii zhurnal - Siberian Pedagogical Journal, 1, 158-166. [in Russian].

10. Germenevtika: istoriia i sovremennost (1986). Moskva: Mysl. [in Russian].

11. Merezhko, A. A. (2003) Iuridicheskaia germenevtika i metodologiia prava. Problemi filosofii prava - Problems of philosophy of law. Vol. 1, 159-162. [in Russian]. 
Ховпун А. С., кандидат юридических наук, доцент, заведующий кафедрой уголовного права,

процесса и криминалистики

Академии труда, социальных отношений и туризма (г. Киев, Украина)

\section{ЗНАЧЕНИЕ ГЕРМЕНЕВТИЧЕСКОГО МЕТОДА АДМИНИСТРАТИВНО-ПРАВОВОГО ОБЕСПЕЧЕНИЯ ФАРМАЦИИ}

Статья посвящена выяснению значения герменевтического метода административно-правого обеспечения фармации. Доказано, что применение герменевтического метода способствует полноте толкования норм закона на уровне идеи, текста, речи. Установлено, что герменевтический метод познания позволяет проводить интерпретацию текстов нормативных актов, иных правовых источников, с учетом исторических, идеологических, экономических, психологических, социологических обстоятельств принятия и применения закона. Обосновано, что понимание, толкование и применение фармацевтического законодательства должны быть ограничены абсолютной ценностью - жизнью человека и его здоровьем.

Ключевые слова: фармация, методы, герменевтика, герменевтический метод, научное исследование.

Khovpun O.,

Candidate of Law, Associate Professor, Head of the Department of Criminal Law, process and criminology Academy of Labor, Social Relations and Tourism (Kyiv, Ukraine)

\section{THE SIGNIFICANCE OF THE HERMENEUTIC METHOD IN THE STUDY OF ADMINISTRATIVE AND LEGAL PROVISION OF PHARMACIA}

The purpose of the article is to clarify the significance of the hermeneutic method in the research of administrative and legal provision of pharmacia. It has been proved that the application of the hermeneutic method contributes to the completeness of the interpretation of the law norm at the level of idea, text, speech. Due to this method the procedure of interpreting the law includes the following stages: understanding the law (in terms of text symbols, i.e. without subjective analysis), its interpretation and application. It has been proved that objectivism is the main principle for understanding, interpreting and applying the law, in the aspects of hermeneutics, which involves the direct application of the law. It has been established that the hermeneutic method of cognition allows to carry out the interpretation of texts of regulatory acts, other legal sources, taking into account the historical, ideological, economic, psychological, sociological circumstances of the adoption and application of the law. The legal hermeneutic method has a special subject matter - the text of the law, other legal sources. Its application should be dominated by the principles of truth, objectivity, universality; the secondary principle is the principle of sufficiency. It has been indicated that the use of the hermeneutic method while studying administrative and legal provision of pharmacia contributes to the interpretation of the text of the law. It 
has been suggested that the understanding of the interpretation of pharmaceutical legislation in fact should be limited by the absolute value - human life and health. It has been emphasized that it is advisable to give priority to human interests in case of a double interpretation of the norms of pharmaceutical law. The author has emphasized the need to establish the balance of interests that provides a fair balance. However, in case of a threat to human life, the completeness of proportionality may be violated.

Keywords: pharmacia, methods, hermeneutics, hermeneutic method, scientific research. 